\title{
REDUCTION OF RESIDUAL N-BUTYL ACRYLATE SENSITIZER IN RADIATION VULCANIZED NATURAL RUBBER LATEX
}

(Received on April 17, 1995)

\author{
Wang Chunlei ${ }^{* 1}$, Fumio YOSHII*2, \\ Kenichiro HYAKUTAKE ${ }^{* 2}$, Keizo MAKUUCHI*2
}

\begin{abstract}
Radiation vulcanization of natural rubber latex needs n-butyl acrylate ( $n-B A)$ to lessen required irradiation dose. Considerable amount of $n-B A$ remains in the latex after the completion of radiation vulcanization and tends to pollute the working environment in a dipping factory. A study has been carried out to reduce the residual n-BA after the radiation vulcanization. About $40 \%$ of added $n-B A$ was found in the latex after irradiation to $20 \mathrm{kGy}$. Hydrolysis of $n-B A$ was effective for reduction of the residual $n-B A$ in the latex. No $n-B A$ was found in the latex when the latex was stored for 4 weeks at room temperature due to its hydrolysis. Heating of the latex was effective to accelerate the rate of hydrolysis of $n-B A$. Almost all of n-BA in the latex was hydrolyzed when the latex was heated for 4 hours at $80^{\circ} \mathrm{C}$. Tensile strength of the latex films slightly decreased by heating treatment of the latex, but gradually recovered as storage time extended. Low viscosity was attained by the heat treatment of the latex.
\end{abstract}

Key word radiation vulcanization, natural rubber latex, $n$-butyl acrylate, hydrolysis, gas chromatography

\section{Introduction}

Crosslinking of rubbery materials is termed vulcanization. Radiation vulcanization of natural rubber latex (RVNRL) means radiation crosslinking of natural rubber (cis-1, 4polyisoprene) dispersed in aqueous medium in

*1 Radiation Center, Suzhou Medical College, 48 Ren Min Road, Suzhou, Jiangsu Province, People's Republic China

*2 Takasaki Radiation Chemistry Research Establishment, Japan Atomic Energy Research Institute, 1233 Watanuki, Takasaki, Gunma, 370-12, Japan the form of fine particles. RVNRL can be accomplished by irradiating NR latex with $\gamma$-rays or electron beams. However, it needs more than $200 \mathrm{kGy}$ to achieve the maximum tensile strength of dried film from irradiated latex ${ }^{1)}$, which is too high to be used in industry. Thus a search for a suitable vulcanization accelerator that is an additive to reduce the required dose was indispensable for industrial application of RVNRL. The vulcanization accelerator has to be non-toxic, available in market and low price. Carbon tetrachloride ${ }^{2)}$, polyfunctional monomers (containing two or more polymerizable 
$\mathbf{C}=\mathbf{C}$ double bonds in a molecule $)^{3), 4)}$, and monofunctional acrylic monomers were proposed as vulcanization accelerators ${ }^{5), 6)}$. In practice, carbon tetrachloride is not acceptable in industries because it is toxic not only to the human body but to the environment. The polyfunctional monomers are not favorable for RVNRL due to their skin irritations. At present, among monofunctional acrylic monomers $\mathrm{n}-\mathrm{BA}$ is believed to be the best vulcanization accelerator because no $\mathrm{n}-\mathrm{BA}$ is remained in dipped products ${ }^{7)}$. This is due to its high vapor pressure that facilitates evaporation during drying process of the products. The crosslinking mechanism of NR with monofunctional acrylic monomer consists of the graft polymerization of acrylic monomers onto NR and recombination of growing polymer radicals with rubber radicals ${ }^{8)}$.

In general, vulcanization of NR latex is performed by means of sulfur and dithiocarbamates. The most significant advantages of RVNRL are the adsence of $\mathrm{N}$-nitrosamine ${ }^{9)}$ and very low cytotoxicity of the products ${ }^{10)}$ due to the absence of dithiocarbamate. In addition, rubber products from the radiation vulcanized (RV) NR latex have the following features:

1) easy degradation in the environment ${ }^{11)}$

2) fewer amounts of rubber proteins that cause allergic response ${ }^{12)}$.

3) transparency and softness ${ }^{7)}$, and

4) low emission of sulfur dioxide and less formation of ashes on combustion ${ }^{7)}$,

However, some parts of the added n-BA tend to remain unpolymerized in the RV NR latex. The remained $n-B A$ causes air pollution in a dipping factory unless the sufficient ventilation is provided. Complete polymerization of n-BA by irradiation is not practical because further irradiation beyond the vulcanization results in lowering the tensile strength. In this paper, the amount of residual $\mathrm{n}-\mathrm{BA}$ has been determined quantitatively and methods for reducing the residual $\mathrm{n}-\mathrm{BA}$ were demonstrated.

\section{Experimental}

\subsection{Materials and irradiation}

Industrial grade $\mathrm{n}-\mathrm{BA}$ and analytical grade hexane, toluene, butanol $(\mathrm{BuOH})$ and potassium hydroxide $(\mathrm{KOH})$ were used without further purification. A commercial high ammonia natural rubber latex (IOTEX dry rubber content, DRC 60\%) from Malaysia was used for radiation vulcanization. The NR latex was diluted to DRC $50 \%$ with $1 \%$ aqueous ammonia solution. While stirring, 0.2 phr $\mathrm{KOH}^{6)}$ and $5 \mathrm{phr} \mathrm{n}-\mathrm{BA}$ were added into diluted latex. Stirring was continued for about half an hour using a magnetic stirrer. Then the NR latex was exposed to $\gamma$-rays from ${ }^{60} \mathrm{Co}$ at a dose rate of $10 \mathrm{kGy} / \mathrm{h}$. Heat treatment of the RV NR latex was performed in sealed glass bottle at given temperature for 4 hours in a thermostatic oven.

\subsection{Determination of $\mathrm{n}-\mathrm{BA}$ and $\mathrm{BuOH}$ in RV NR latex}

Analysis of $\mathrm{n}-\mathrm{BA}$ and $\mathrm{BuOH}$ was carried out by gas chromatography. Operating conditions of a gas chromatograph (GC) were listed in Table 1. Five grams of the RV NR latex were completely transferred to a $50 \mathrm{ml}$ volumetric flask with hexane followed by addition of $5 \mathrm{ml}$ toluene as internal standard. The sample was diluted to $50 \mathrm{ml}$ with hexane and shaken in vibrator for 3-4 hours to completely extract the residual $\mathrm{n}-\mathrm{BA}$ to hexane. Then $1 \mu \mathrm{l}$ hexane solution was injected into GC. Measurement was carried out immediately after irradiation.

\subsection{Measurements of physical properties}

The film about $0.8 \mathrm{~mm}$ thickness was prepared by casting the RV NR latex onto a glass plates $\left(12 \times 18 \mathrm{~cm}^{2}\right)$. They were dried in air at room temperature (about $20^{\circ} \mathrm{C}$ ) until they became transparent and then immersed in $1 \%$ aqueous ammonia solution (leaching) for 24 hours followed by drying at room temperature until transparent. Subsequently, the films were heated at $80^{\circ} \mathrm{C}$ for half an hour. 
Table 1 Operating conditions of gas chromatograph

\begin{tabular}{l|c}
\hline \multicolumn{1}{c|}{ Item } & Condition \\
\hline Gas Chromatograph & Shimadzu GC-RlA \\
Column & $\mathrm{G}-300(15 \mathrm{~m})$ \\
Detector & $\mathrm{FID}$ \\
Injection Temperature & $100^{\circ} \mathrm{G}$ \\
Column Temperature & $50^{\circ} \mathrm{G} \rightarrow 200^{\circ} \mathrm{C}\left(5^{\circ} \mathrm{C} / \mathrm{min}\right)$ \\
Carrier Gas & $\mathrm{N}_{2}$ \\
Carrier Gas Rate & $35 \mathrm{ml} / \mathrm{min}$ \\
$\mathrm{H}_{2}$ Pressure & $0.5 \mathrm{~kg} / \mathrm{cm}^{2}$ \\
Air Pressure & $0.2 \mathrm{~kg} / \mathrm{cm}^{2}$ \\
\hline
\end{tabular}

After cooling, the films were cut to dumbbell shape and conditioned at $20^{\circ} \mathrm{C}$ over night in a desiccator. The tensile strength of film was measured according to JIS K 6301 with Strograph-R1 tension meter (Toyoseiki Co. Ltd.). Viscosity of the latex was measured with a viscometer, Visconic ED (Tokyo Keiki Co. Ltd.)

\section{Results and discussions}

\subsection{Determination of $\mathbf{n}-\mathbf{B A}$ in NR latex}

The solubility of $\mathrm{n}-\mathrm{BA}$ in water is $0.14 \mathrm{~g} /$ $100 \mathrm{ml}$ at $20^{\circ} \mathrm{C}^{11)}$ and $1,375 \mathrm{~g}$ of $\mathrm{n}-\mathrm{BA}$ can be absorbed in $100 \mathrm{~g}$ of dry $\mathrm{NR}$ at $25^{\circ} \mathrm{C}$ for 4.5 hours $^{3)}$. Accordingly, more than $95 \%$ of $n-B A$ are supposed to be distributed in rubber particles in NR latex. Efforts had been made to find a suitable analytical method of $n-B A$ in the latex. Direct injection of diluted NR latex into GC often caused clogging of microsyringe and resulting in poor reproducibility. Steam distillation of the RV NR latex was found to enhance hydrolysis of $n-B A$. Then extraction of $n-B A$ in the latex with organic solvent seemed to be practical. Among several organic solvents, methanol, ethanol, acetone and tetrahydrofuran caused flocculation and aggregation that tightly stuck to container wall. Thus the completely extraction of $n-B A$ from the latex was difficult by use of these solvents.

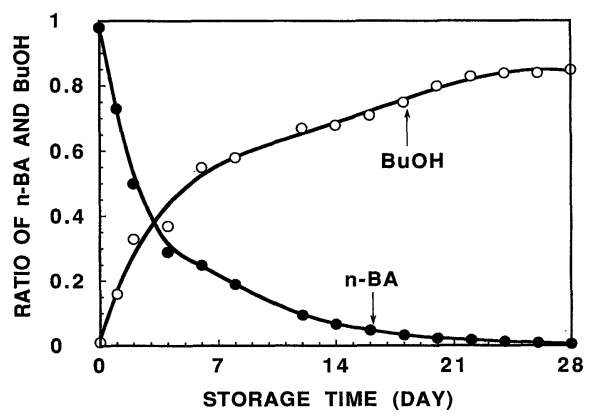

Fig. 1 Changes in concentrations of n-BA and $\mathrm{BuOH}$ in $\mathrm{NR}$ latex kept at room temperature (about $20^{\circ} \mathrm{C}$ )

Benzene, toluene and xylene gave less aggregation. Hexane was found superior to them because it led to latex aggregation in the form of small particles that did not stick to each other and to the container wall. Thus a good extraction method was established as described in the experimental part.

\subsection{Hydrolysis of $\mathrm{n}-\mathrm{BA}$ in NR latex}

It is expected that ammonia in NR latex will catalyze the hydrolysis of $n-B A$. As a result of hydrolysis acrylic acid and butanol $(\mathrm{BuOH})$ are formed.

$$
\mathrm{n}-\mathrm{BA}+\mathrm{OH}^{-}=\text {Acrylic acid }+\mathrm{BuOH}
$$

Figure 1 shows the changes in concentration of $\mathrm{n}-\mathrm{BA}$ in the non-irradiated NR latex kept at room temperature (about $20^{\circ} \mathrm{C}$ ). Concentration of $n-B A$ decreased with increasing storage period and $20 \%$ of $n-B A$ was diminished in 10 hours. After one month no n-BA was detected. As expected $\mathrm{BuOH}$ is detected and its concentration increased with increasing the storage period. This indicates that the diminishing of $\mathrm{n}-\mathrm{BA}$ is due to the hydrolysis of $\mathrm{n}-\mathrm{BA}$ catalyzed by ammonia.

The rate of hydrolysis was analyzed based on the above reaction scheme (first-order reaction).

$$
\text { In }[\mathrm{n}-\mathrm{BA}]_{0} /[\mathrm{n}-\mathrm{BA}]_{\mathrm{t}}=k_{1} t
$$

Where $k_{1}$ is the rate constant of the hydrolysis, $[\mathrm{n}-\mathrm{BA}]_{0}$ and $[\mathrm{n}-\mathrm{BA}]_{\mathrm{t}}$ are the initial concentra- 


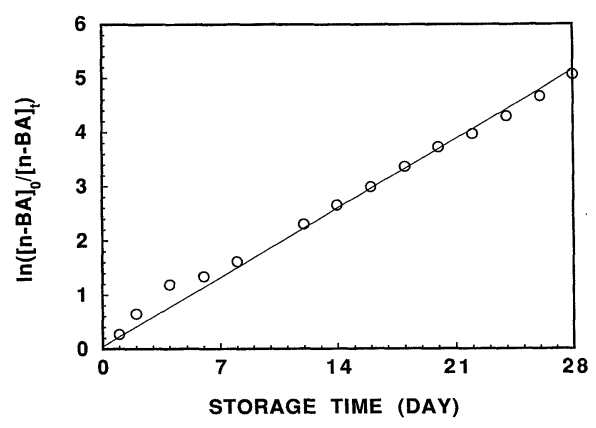

Fig. 2 Relationship between storage time and $\ln$ $[\mathrm{n}-\mathrm{BA}]_{0} /[\mathrm{n}-\mathrm{BA}]_{\mathrm{t}}$

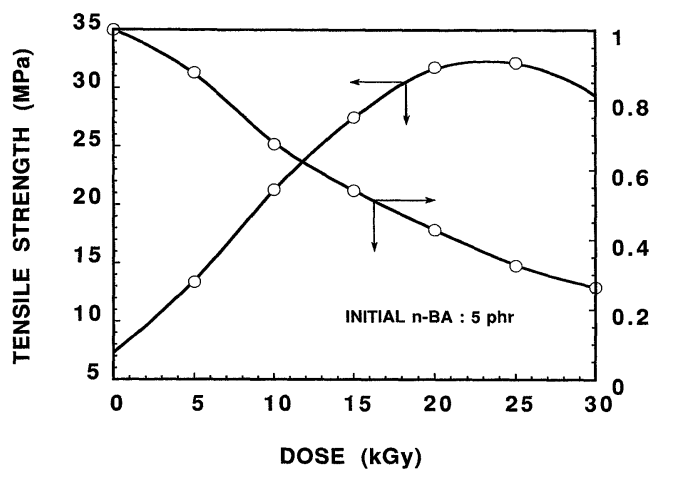

Fig. 3 Effect of radiation dose on tensile strength of RV NR latex film and residual $n-B A$ in RV NR latex

tion of $\mathrm{n}-\mathrm{BA}$ and the concentration of remained n-BA after a time of $t$., respectively. Linear relationship between $t$ and $\ln [\mathrm{n}-\mathrm{BA}]_{0} /[\mathrm{n}-\mathrm{BA}]_{\mathrm{t}}$ was found as shown in Fig. 2. The rate constant $k_{1}$ thus obtained is $1.3 \times 10^{-4} \mathrm{~min}^{-1}$. These facts indicate that the NR latex should be irradiated immediately after the addition of $n^{-}$ BA.

\subsection{Residual n-BA in RV NR latex}

Figure 3 shows effect of radiation dose on the tensile strength of the RV NR latex film and residual $\mathrm{n}-\mathrm{BA}$ in the RV NR latex. Maximum strength of about $30 \mathrm{MPa}$ was obtained at 20 $\mathrm{kGy}$. The concentration of residual $\mathrm{n}-\mathrm{BA}$ decreased exponentially against dose. Forty percent of $n-B A$ is still remained at the vulcaniza-

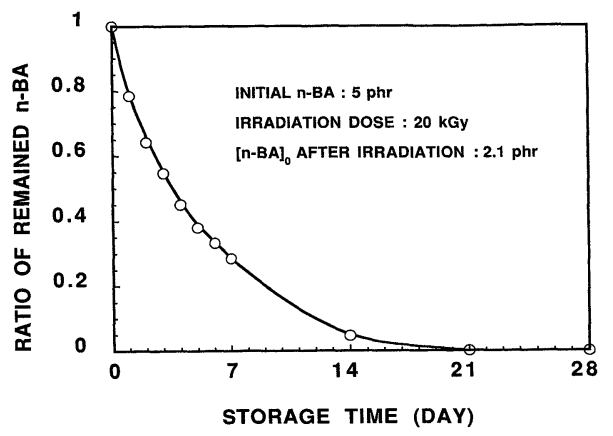

Fig. 4 Changes in concentrations of n-BA in latex exposed to $20 \mathrm{kGy}$ and stored at room temperature $\left(25^{\circ} \mathrm{C}\right)$

tion dose of $20 \mathrm{kGy}$. According to the first-order reaction kinetics, the rate of polymerization of $\mathrm{n}-\mathrm{BA}$ by radiation was calculated as $R_{p}=74 \times$ $10^{-4} \mathrm{~min}^{-1}$. Thus the rate of radiation polymerization of $n-B A$ at a dose rate of 10 $\mathrm{kGy} / \mathrm{h}$ is much larger than the that of hydrolysis of $\mathrm{n}-\mathrm{BA}$ in the latex at room temperature. However, the hydrolysis of $n-B A$ during irradiation may affect the rate of RVNRL at low dose rate.

\subsection{Reduction of $\mathbf{n}-\mathbf{B A}$ during storage}

Figure 4 shows the changes in the remained $n-B A$ in the RV NR latex kept at room temperature $\left(20^{\circ} \mathrm{C}\right)$. It is obvious that $n-B A$ in the RV NR latex decreased with increasing storage time. Residual n-BA was reduced from $40 \%$ to $11 \%$ in 7 days. No $n-B A$ smell exists in the RV NR latex when the latex kept 2 weeks. Finally, after 4 weeks no n-BA is detected in the latex by GC. From these findings, it is necessary to store the RV NR latex for more than 2 weeks at room temperature to reduce the residual $\mathrm{n}-\mathrm{BA}$ to an acceptable level. No effect on the mechanical properties of the RV NR latex films was observed during storage of the latex for three months. This means storage of the RV NR latex is an effective method to reduce the residual $n-B A$ without lowering tensile strength. 


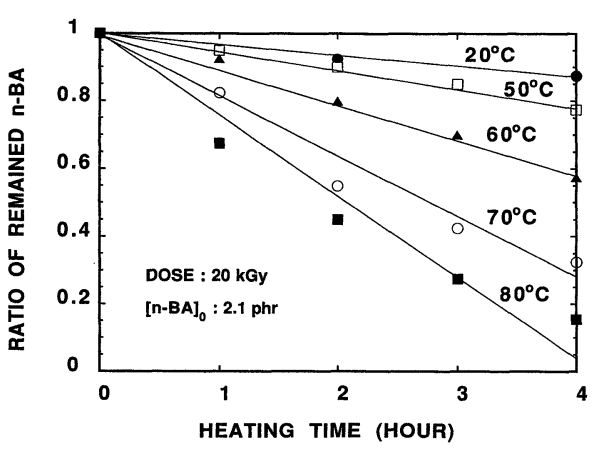

Fig. 5 Effect of heat treatment of RV NR latex on concentration of residual $n-B A$

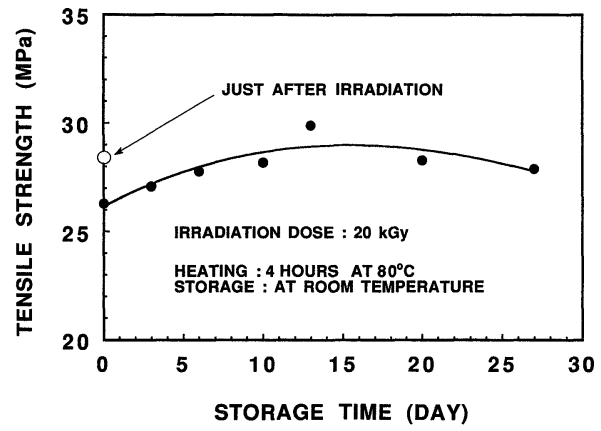

Fig. 6 Recovery of tensile strength of heated RV NR latex during storage at room temperature

\subsection{Acceleration of hydrolysis of residual n-BA}

To accelerate hydrolysis of residual $\mathrm{n}-\mathrm{BA}$, the RV NR latex is heated up to $80^{\circ} \mathrm{C}$. Figure 5 shows the effect of heating temperature on the decay of residual n-BA. Evidently, the concentration of remaining $\mathrm{n}-\mathrm{BA}$ in the RV NR latex decreases remarkably with increasing temperature and no $\mathrm{n}-\mathrm{BA}$ is detected in the latex that was heat-treated at $80^{\circ} \mathrm{C}$ for 4 hours. This indicates that high temperature treatment such as at $80^{\circ} \mathrm{C}$ is more effective to reduce the residual $\mathrm{n}-\mathrm{BA}$ than to store the latex at room tempetature. Activation energy of the hydrolysis calculated from these date by Arrhenius plot method is $15 \mathrm{kcal}$.
Table 2 Effect of latex heating for 4 hours at various temperatures on tensile strength of the RV NR latex film

\begin{tabular}{l|c|c|c|c|c}
\hline Temperature $\left({ }^{\circ} \mathrm{C}\right)$ & r.t & 50 & 60 & 70 & 80 \\
\hline Tensile strength $(\mathrm{MPa})$ & 28.8 & 28.1 & 28.7 & 27.6 & 26.5 \\
\hline r.t room temperature $\left(20^{\circ} \mathrm{C}\right)$
\end{tabular}

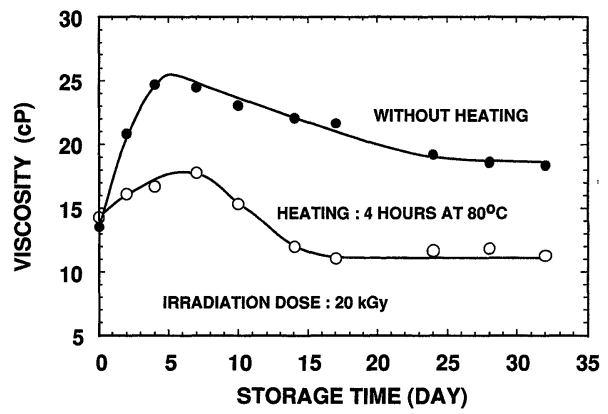

Fig. 7 Effect of latex heating on viscosity of RV NR latex

Effect of latex heating on the tensile strength of the RV NR latex is summarized in Table 2. The tensile strength slightly decreases with increasing heating temperature. Interestingly, improvement of the strength was accomplished during storage more than five days at room temperature as shown in Fig. 6. This is probably due to the reversible structural change in the adsorbed layers on the rubber particles ${ }^{14)}$.

Another effect of latex heating was observed in the viscosity of the RV NR latex as shown in Fig. 7. The viscosity of the RV NR latex increased and passed through the maximum in initial few days and then fell off, regardlss of the heat treatment. This is also due to the reversible structural change in the adsorbed layers on the rubber particles ${ }^{14)}$. The degree of viscosity change for the heat-treated latex is less than that of the unheat-treated latex. Therefore it can be said that the heat treatment is effective to stabilize the RV NR latex.

Addition of $\mathrm{KOH}$ to the RV NR latex was 


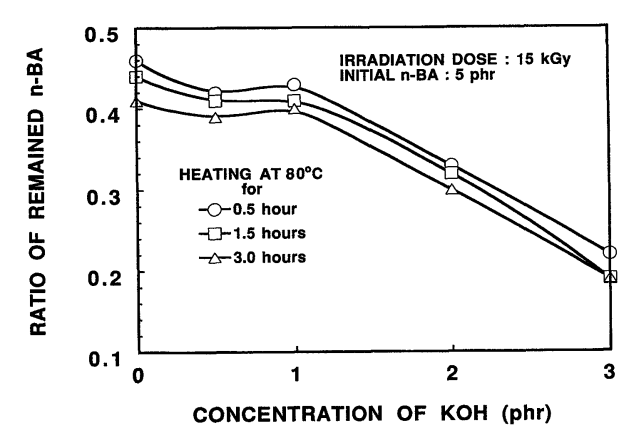

Fig. 8 Effect of addition of $\mathrm{KOH}$ on concentration of residual $\mathrm{n}-\mathrm{BA}$

also attempted to accelerate the hydrolysis at $80^{\circ} \mathrm{C}$. However, this method seems impractical because more than $1 \mathrm{phr}$ of $\mathrm{KOH}$ is needed for the acceleration as shown in Fig. 8.

\section{Conclusion}

Hydrolysis of $n-B A$ is useful to reduce the residual $\mathrm{n}-\mathrm{BA}$ in the RV NR latex. Simple method is to keep the RV NR latex for 2 weeks at room temperature. The tensile strength of the RV NR latex film is almost stable in such duration. Heat treatment of the RV NR latex is effective to accelerate the hydrolysis of $n-B A$. No $\mathrm{n}-\mathrm{BA}$ is detected in the latex kept for one day after heating at $80^{\circ} \mathrm{C}$ for 4 hours. The stability of the RV NR latex is also improved by the heating. Tensile strength of the RV NR latex film slightly decreases with increasing heating temperature but recovers as storage time extends. In conclusion, heat treatment of the RV NR latex is a practical method to diminish the residual $n-B A$ in the $R V$ NR latex.
A preliminary report of this work was presented at the 7th Discussion Meeting of Elastomers, The Society of Rubber Industry, Japan, Tokyo, December 1993.

\section{References}

1) Minoura, Y., Asano, M.: J. Appl. Polym. Sci., 5, 233 (1961)

2) Minoura, Y., Asano, M.: J. Appl. Polym. Sci., 5, 401 (1961)

3) Makuuchi, K., Hagiwara, M.: J. Appl. Polym. Sci., 29, 965 (1984)

4) Makuuchi, K., Hagiwara, M.: Radiat. Phys. Chem., 24, 203 (1984)

5) Makuuchi, K., Tsushima, K.: Nippon Gomu Kyokaishi, 61, 478 (1988)

6) Chen, Z., Makuuchi, K.: Proc. Intern. Symp. Radiat. Vulc. Nat. Rubb. Latex", JAERI-M 89-228, Tokyo, Japan (1990), p. 326

7) Makuuchi, K., Yoshii, F., Ishigaki, I., Tsushima. K., Mogi, M., Saito, T.: Radiat. Phys. Chem., 35, 154 (1990)

8) Chygrit Siri-Upathum, Makuuchi, K., Ishigaki, I., Ṗroc. Intern. Symp. Radiat. Vulc. Nat. Rubb. Latex", JAERI-M 89-228, Tokyo, Japan (1990) , p.336

9) Gazeley, K. F., Pendle, T. D.: Proc. Intern. Symp. Radiat. Vulc. Nat. Rubb. Latex", JAERI-M 89-228, Tokyo, Japan (1990), p. 189

10) Tsuchiya, T., Ikarashi, Y., Uchima, T., Miyahara, T., Takahashi, M., Nakamura, A.: Radiat. Phys. Chem., 39, 541 (1992)

11) Adul Thiangghanya, Makuuchi, K., Yoshii, F.: J. Appl. Polym. Sci., 54, 525 (1994)

12) Makuuchi, K., Yoshii, F., Hyakutake, K., Kume, T., K. Suzuki, K.: Nippon Gomu Kyokaishi, 68, 263 (1995)

13) The Merck Index", Eighth Ed., Merck \& Co., Int., (1968), p. 178

14) Davies, R. T., Pendle, T. D.: J. Nat. Rubb. Res., 6, 12 (1991) 